\title{
Centering the Periphery: Manchurian Exile(s) and the North Korean State
}

\author{
Charles K. Armstrong
}

Kim Il sung and other Manchurian guerrilla veterans who came to dominate North Korean politics after 1945 were profoundly influenced by the experience of their antiJapanese struggle in exile. This influence has shaped the ideology, historiography, and domestic and external policies of the DPRK to the present. At the same time, this exile experience has been given a mythical status in North Korean history, centered on the personality and activities of Kim Il Sung, but reflective of earlier attempts to draw Manchuria into the mainstream of Korean history. The "mythification" of Manchuria has grown steadily over time, and since the early 1970s Kim Jong II has been closely associated with his father's Manchurian guerrilla struggle, in particular with the image of Mt. Paektu.

The February 1994 issue of Korea Today, one of the glossy magazines depicting the paradisiacal state of life in North Korea, has on its front cover the Lake of Heaven (Ch'ŏnji) on Paektusan (or Paektu [whitehead] Mountain), on the Sino-Korean border. On the inside cover is pictured a pristine alpine lake near the base of Paektusan, which was allegedly visited by the Dear Leader Kim Jong Il in the autumn of 1971 , who sat by its banks and "gave deep thought to the future of the Korean revolution while angling." In the last few years, the February issue of these magazines (Kim Jong Il's birthday is in February) have all had special sections on the alleged "secret guerrilla camp" on Paektusan and the birthplace of Kim Jong 11, both of which are historical fictions. Nevertheless, the apparatuses of North Korean ideology have made great efforts to link the younger Kim with his father's guerrilla struggles in Manchuria, and with Paektusan in particular. I will argue that such a connection is not arbitrary. The purpose of this identification is not merely to associate the younger Kim with the formative experiences of his father and fellow guerril- 
las, a struggle which has long since surpassed history to take the form of myth. Paektusan itself is important as a powerful symbol of Korean history and culture, and its image lends an aura of legitimacy to Kim Il Sung's chosen heir.

The tallest mountain in the Changbaishan range dividing Korea from Manchuria, Paektusan has long been a symbol of Korean national identity in both North and South. Its height, its eerily rugged appearance, and the spectacular crater lake at its peak have contributed to Paektusan's prominence in the myths of several Northeast Asian cultures. The Manchus, the Mongols, and the Koreans all have myths that their people originated on Paektusan; one Korean myth has it that Tangun, ancestor of the Korean people, was born on the peak of Paektusan. Paektusan figures in Chinese mythology as well, as one of a chain of sacred mountains linked to the most sacred mountains of all, the K'unlun chain in the far west. ${ }^{2}$ More immediately for North Korea, Paektusan and Manchuria as a whole are important as the site of the anti-Japanese guerrilla struggle out of which emerged much of the postliberation DPRK leadership, including Kim Il Sung.

The purpose of this paper is to explore how the nation is dreamed in exile, and how an experience of exile is in turn dreamed or reimagined by the state that comes to represent the nation; how Manchuria and Paektusan in particular, areas peripheral to or actually outside of the geographical boundaries of Korea, come to occupy a central space in the construction of North Korean state mythology after liberation. In short, I would like to spend some time fishing with Kim Jong Il, and if possible share in his languid daydreams of the Korean revolution.

\section{Shin Ch'ae-ho and the Exile Origins of Nationalist Historiography}

Lord Acton, who is famous for a number of pithy sayings, once remarked that "exile is the nursery of nationality." ${ }^{3}$ One can dispute his infantile imagery; nevertheless, it does seem apparent that modern nationalism, especially for what we have come to call the "Third World," is often first articulated by those who have left their country of origin, often for the colonial metropole. Nationalism, though a discourse of the modern West, is articulated against the colonial power itself and answers the disruptions of capitalism and colonialism with the defensive solidarity of communal identity. As Homi Bhabha puts it, "The nation fills the void left in the uprooting of communities and kin, and turns that loss into the language of metaphor." It is perhaps exiles who feel the loss of a nation most acutely, and who-ironically-see themselves as most qualified to define what the nation is.

Japanese colonialism created such a sense of loss among a great many Korean intellectuals who saw Korea's nation-building project cut short by Japan's theft of Korean autonomy. Many left Korea for China, Russia, Japan, 
and the United States, which became competing centers of the independence movement. But it is Manchuria, a peripheral area with an ambiguous relationship to Korean history, that creates a particularly interesting type of nationalist articulation that becomes extremely important before and after liberation, especially in the North.

We can begin with Shin Ch'ae-ho, considered the father of modern Korean historiography, who invents Korean history from Chinese exile. In April 1910, Shin and other members of the nationalist Shinminhoe crossed the Yalu river into Manchuria. ${ }^{5}$ China was not the colonial metropole, but it was the focus of a political and intellectual dependence that Shin despised, and the source of a Confucian orthodoxy that he felt had systematically denied Korea's autonomous history. Shin carefully utilized Sinocentric traditional histories to undermine Sinocentrism, which he felt was the necessary first step to Korean autonomy and national identity. Before Korea could identify itself against the colonial Other, it first had to separate its identity from its historical Other, China, and to do so in the interstitial space between China and Korea. What Koreans must first do, Shin argued, was to overcome their subservient mentality (sadae ŭishik) and to develop an "autonomous spirit" (chuch'e $\breve{u i}$ chŏngshin), and this could only be accomplished with a Korea-centered nationalist history. ${ }^{6}$

Along the way, Shin reintegrated Manchuria into Korean history. He was particularly critical of the Samguk sagi for excluding Parhae and Puyŏ from Korean history, and he devoted his most important historical work, the Chosŏn sangosa, to the history of Koguryŏ. Shin wandered Northern China and Manchuria and drew inspiration from his visits to the ruins of Koguryŏ, as well as Paektusan. ${ }^{7}$ All of his major historical work was written during this exile experience, as well as his unfinished novel Kkum hanŭl (Dream heaven), which is not so much a historical novel as an exploration of self-identification with Korean national history. Shin seems quite literal in his famous statement in the introduction of the Chosŏn sangosa-"History is the record of struggle between the 'I' and the 'non-I' "-inasmuch as the individual must totally identify himself with the nation, and the nation in turn is the subject-centered self of history. ${ }^{8}$ Shin Ch'ae-ho's other major historical work, the Chosorn sango munhwasa, dealt with the myth of Tangun, whom Shin saw as the necessary starting point of Korean history, both as the founder of the Korean race (minjok) and of the first Korean state $(k u k){ }^{9}$

\section{Living on the Margins}

By the time Shin Ch'ae-ho died in a Japanese prison in 1936, Manchuria had become the most active center of a nationalist armed resistance against Japanese colonialism. Among the many guerrilla groups was the organization with which Kim Il Sung and other future North Korean leaders were involved, 
the Northeast Anti-Japanese United Army (Dongbei kangri lianjun), a joint Chinese-Korean organization under the command of the Chinese Communist Party. The current leaders of the DPRK have attributed tremendous historical significance to the anti-Japanese armed struggle in this area, and however exaggerated may be their claims of military success or Korean autonomy (to be discussed below), it is undeniable that the guerrilla struggle in this region was the formative experience for those who ultimately came to power in North Korea, and as such profoundly influenced the shaping of the new political and social system created in the North.

Thus, a new state and society for North Korea were imagined at the interstices of colonial control and unregulated frontier, at the meeting point of rootless intellectuals, political exiles, foreign influence, and a poor but mobile and relatively independent peasantry. ${ }^{10}$ Such elements were thrown together out of the unprecedented dislocation and mobility of the Japanese colonial project in Korea, later extended to Manchuria, which introduced a new capitalist and imperialist "nomadism" to a previously sedentary Korean society. ${ }^{11}$

The Sino-Korean border region had for centuries been an area of exile, escape, and experimentation. A general decline in rural living standards throughout the nineteenth century had already disrupted Korean peasant society by the time the Japanese took over. One consequence of poverty and social dislocation was frequent peasant rebellion; another was a marked increase in vagrancy and migration. ${ }^{12}$ Many were forced into the mountains to attempt a livelihood in precarious slash-and-burn hillside agriculture. Such people were known as hwajŏnmin ("fire-field people"). This form of agricultural production, predominantly located in the northernmost areas of North P'yŏngan, South and North Hamgyŏng provinces, is an economy of mobility and independence, in contrast to the sedentary tenant-based farming of the south. ${ }^{13}$ But even the remote mountains of northeast Korea were accessible to the extractive hand of the state, and many peasants moved still farther north, into Manchuria and Siberia. ${ }^{14}$

Manchuria in particular was a place of opportunity for the displaced Korean peasant. Despite centuries of contact between Chinese, Jurchen, Mongol, and Korean peoples in this region, Manchuria was in many ways a "new frontier" at the end of the nineteenth century. From the late seventeenth century, the Qing government had restricted migration into the Northeast in an attempt to preserve the Manchu "homeland" as a pristine natural environment, but by the middle of the nineteenth century foreign encroachment, first by the Russians and then by the Japanese, forced the dynasty to adjust its Manchurian policy in order to keep the Northeast in the Qing orbit. ${ }^{15}$ All restrictions on Chinese migration into Manchuria were lifted by $1904,{ }^{16}$ and natural disaster, civil war, and economic hardship in North China caused as many as eight million Chinese to move to Manchuria during the first half of the twentieth century. ${ }^{17}$ 
Koreans began emigrating to Manchuria in large numbers from the latter part of the nineteenth century, especially after the famines and peasant uprisings of the $1860 \mathrm{ss}^{18}$ Initially most Korean immigrants were from the Hamgyŏng provinces, but after Japan annexed Korea in 1910 most new immigrants came from the P' yŏngan provinces or southern Korea. ${ }^{19}$ Nevertheless, it was primarily the immigrants from Hamgyŏng who formed the core population of the Korean community in Jiandao (Kando in Korean), the region of eastern Manchuria on the banks of the Tumen river across from Korea that is now the Yanbian Korean Autonomous Region of China's Jilin Province. To this day, the language spoken by most Koreans in Yanbian is based on the Hamgyŏng dialect. ${ }^{20}$

By 1920, the Korean population in Manchuria was over 400,000; by 1931 , it was over $900,000,64$ percent of whom resided in Jiandao, where they outnumbered the Chinese residents three to one. ${ }^{21}$ After the creation of Manchukuo in 1932 and Japanese encouragement of Korean emigration to Manchuria, the Korean population expanded still further, approaching two million by 1945 . Koreans engaged in a highly productive form of paddy rice cultivation on the fertile Manchurian soil, although at first Korean farmers were not allowed to own land and worked for Chinese and Manchu landlords. ${ }^{22}$ The Korean population of Northeast China was largely peasant, and from quite impoverished backgrounds at that; they were drawn to Manchuria by the opportunity to improve their livelihood and escape economic misery at home. ${ }^{23}$ But among the poor peasants were a significant number of brigands, outlaws, petty capitalists, and-increasingly—political renegades and anti-Japanese nationalists.

As a frontier region, Manchuria was an area of opportunists and vagabonds, political exiles and bandits, self-made men and self-governing peasant villages. For a century Manchuria was the focus of international rivalry, and as China declined into anarchy and Russia and Japan struggled for control of this vast hinterland, the absence of effective state power in the region allowed a space for local autonomy, self-government, antistate resistance, and more than a little criminal behavior. Many settlers were "squatters, wanderers, and outlaws by turn," and illicit opium production played an important part in the local economy. ${ }^{24}$ Moreover, the line between banditry and social reform was not always clear: local bandits known as honghuzi [red beards] were in some places the only "government," and became quite popular at times for their Robin Hood-like redistributive practices..$^{25}$ Owen Lattimore remarked that Manchuria probably contained more villages formed by outlaws than any other area in the world, and the British explorer H.E. M. James found "wellorganized, self-governing fugitive settlements" in the Changbaishan region on the Manchuria-Korean border in $1886 .{ }^{26}$ Late Qing policies attempting to reestablish taxation in the region encountered well-organized resistance by local Village Federations (lianchuanghui) established early in this century. ${ }^{27}$ 
It was in this milieu of poor migrants, outlaw bands, clandestine political organization, and local resistance that Korean exiles attempted to forge an armed struggle against Japanese imperialism. From a long-term historical perspective, the communists can be seen as part of a tradition of autonomous outlaw and resistance groups linked with local peasant society. In Manchuria, politically active, exiled intellectuals shared with the local peasants the common characteristics of mobility and marginality, and such displaced, mobile, unattached, and disaffected elements, at the fringes of state control, can create an explosive, indeed revolutionary, combination. ${ }^{28}$

As the Japanese police and military moved in to control Manchuria in the early 1930s, a combination of ruthless force, careful surveillance, and economic incentives "pacified" large segments of the local population, but at the same time pockets of resistance stiffened and became increasingly radicalized, until the last guerrilla bands were driven out in the early 1940s. For a time, then, this peripheral area became the center of anticolonial resistance for an important segment of Korean and Chinese revolutionary nationalists. State control was not fully asserted in this area, and the space for rebellion closed, until 1949, with the communist victory in China's civil war (for which Manchuria was a crucial arena) and the establishment of the DPRK (which drew its most important leadership from the Manchurian struggle).

\section{Anticolonial Struggle}

After the Japanese demobilized the Korean army in 1907, intransigent Korean soldiers created a "Righteous Army" (üibyŏng), which engaged with the Japanese military for several years. By around 1912 the last of the üibyŏng had been defeated, leading a number of remaining activists to retreat to Manchuria and Siberia where they entered the Korean immigrant communities there. Military centers were established to train guerrilla forces for combat across the border in Korea. ${ }^{29}$ The most famous of these former soldiers was probably Yi Tong-hwi, who went into exile with several hundred Korean troops first to the mountains of the north, then to Manchuria, and finally to Siberia, where he founded the first Korean socialist-oriented party, the Hanin sahoedang or Korean People's Socialist Party. Thus, Korean communist armed groups in Manchuria and Siberia were both connected to, and built upon, a tradition of armed rebellion in exile extending back several decades. ${ }^{30}$

It is important to see this as more than an "exile movement" far removed from the activities of Korea proper except for an occasional foray across the border-like the Provisional Government in Shanghai, sending the odd messenger or terrorist across the Yellow Sea to the peninsula. The border between Korea and Manchuria was extremely porous, and in many ways the Korean community in Jiandao was simply an extension of Korea itself; anti-Japanese activities in southeastern Manchuria and northeastern Korea were closely 
linked until the late 1930s. As Se Hee Yoo has pointed out in his study of peasant radicalism in colonial Korea, the Hamgyŏng provinces adjacent to Manchuria had the highest incidence of radical peasant organization and antiJapanese activity in the 1920s and 1930s, largely under the umbrella of the Red Peasant Union (Chŏksaek nongmin chohap, or nongjo), and both information and the activists themselves moved easily back and forth between these provinces and Manchuria and the Soviet Far East. ${ }^{31}$ Traditionally a difficult area for the state to control, the two Hamgyong provinces were a persistent problem for the Japanese authorities until guerrilla movements on both sides of the Korea-Manchuria border were wiped out in the brutal "annihilation campaigns" of the late $1930 \mathrm{~s}^{32}$

\section{Kim Il Sung and the Partisan Movement in Manchuria}

\section{THE ANTI-JAPANESE UNITED ARMY}

There is very little documentation on Kim before 1945 that can be verified as genuine. Most of his writings and the descriptions of his political activities from that period in current North Korean literature are fabrications that have steadily attributed ever greater revolutionary feats to the young Kim as the cult of the Great Leader has developed. The purpose of this material is clearly not history in any scholarly sense, but myth-creation, as will be discussed below. Contemporary references to Kim appear primarily in two places: the records of the Japanese police and the Chinese Communist Party (CCP). A large number of the latter, in the form of memoirs and documents pertaining to the anti-Japanese struggle in the Northeast, have emerged from the People's Republic since the 1980s. Although PRC sources are not without their biases, they seem to be as reliable a guide as can be found to the nature of the Manchurian communist resistance and to Kim's place in it.

Kim's major guerrilla activities were with the CCP-directed Northeast Anti-Japanese United Army (Dongbei kangri lianjun) between about 1934 and 1940. The fact that Kim fought under Chinese command and was himself a member of the CCP has disappeared from North Korean histories, which refer instead to Kim's leadership of a "Korean People's Revolutionary Army" (Chosŏn inmin hyŏngmyŏnggun), based perhaps on the CCP's "Northeast People's Revolutionary Army" (Dongbei renmin gemingjun), in which Kim may have been involved but certainly not as the leader, and which was active in Manchuria from September 1933 until it fell victim to a Japanese "punitive expedition" in February $1936 .{ }^{33}$ On the other hand, the purpose of the Chinese materials is clearly to glorify the CCP and the Chinese Revolution, and the participation of Kim and other Koreans is rarely emphasized. Indeed, Chinese sources give the impression that Korean communists were relatively ineffective, ridden with factionalism and "leftism," until they came under the wise 
leadership of the Chinese Communist Party. ${ }^{34}$ Understandably, both Chinese and North Korean sources downplay or ignore the very real tensions between Korean and Chinese activists, as well as among the population as a whole, but in different ways: the Chinese by making the Koreans an "important minority group" in the Chinese revolution, the Koreans by treating Korean activities as completely independent of the Chinese Communist Party. ${ }^{35}$

There is one interesting critique on the base areas and the guerrilla struggle in Manchuria written by Kim Il Sung himself. Possibly the only verifiable piece of writing by Kim before liberation, this "unit report" on the First Army of the Northeast Anti-Japanese United Army (NEAJUA) was written in 1942 after Kim's retreat to the Soviet Union. ${ }^{36}$ Written in Chinese in a terse, functional style, the report lacks any of the rhetorical flourishes or grandiose statements of the later writings attributed to Kim. Kim gives a frank appraisal of the First Army in which he fought, its successes, its shortcomings, and its ultimate failure. He gives a sense of the difficulty of the anti-Japanese struggle in the face of tremendous physical, geographical, and political obstacles.

In 1932, according to Kim, base areas and "Soviet governments" were established in four provinces of East Manchuria, the area covered by the First Army. Later called "People's Revolutionary Governments," nine areas were created altogether. On 18 November 1933, a Japanese force of about 1000 attacked the guerrillas, who finally repulsed the invaders after a 16-day battle. The cost of their success was high: in Yanji county alone 150 Japanese, but over 500 guerrillas, were killed. The revolutionary bases seem to have been abandoned after 1935 .

In August 1933, the Northeast Anti-Japanese People's Revolutionary Army (NEAJPRA) was created. Kim joined the First Independent Army of the NEAJPRA, which was composed mostly of Koreans, although its commander, Yang Jingyu, was Chinese. (Its political commissar, Song Ch'ŏl-an, was Korean). This seems to be the origin of Kim's later claim to have led a "Korean People's Revolutionary Army" in Manchuria.

Kim notes several "errors" in the East Manchurian guerrilla movement of the early 1930s. First, the guerrillas "engaged with the Japanese unnecessarily several times instead of building forces gradually." Second, they took a "leftist" line against landlords and peasants, as well as refusing to combine forces with other nationalist groups, rather than forming a united front. Third, the constant Japanese surveillance and suspicion of infiltration led to selfdestructive purges. The anti-Minsaengdan struggle in particular led to the deaths of "more than a few innocent comrades." These "left errors" were corrected after 1935 with the establishment of a united front and the NEAJUA.

The period between 1936 and 1939 was a high point for the First Army, in which its forces expanded and engaged successfully with the Japanese. But this period of success was brief. The years 1939 to 1941 "could be called the 
period when our forces suffered loss," as Kim euphemistically puts it. Massive punitive expeditions (datufou) decimated the guerrillas' ranks. In the end there was "too great a gap between the enemy forces and our own." The guerrilla movement, Kim admits, ended in disappointment.

This is not the Kim Il Sung of North Korean state mythology, who led an ever-victorious Korean army in dealing blow after telling blow against a fierce but fallible Japanese imperialist force. But it is the record of an observant and dedicated guerrilla fighter. It describes a group of partisans with a tremendous determination to win against overwhelming odds, willing to take enormous and at times foolhardy risks, who felt themselves the only legitimate representatives of a people oppressed by imperialism and "feudal vestiges," and who attempted to link themselves with the poor peasantry of the remote Manchurian countryside in order to win back for them the land stolen by ruthless invaders. It was an experience that fostered determination, secrecy, united front tactics, and an emphasis on mobilizing the marginal elements of society - including poor peasants, women, and youth-as well as a lack of tolerance for dissent, a ruthlessness toward the enemy, a driving nationalism, and a fierce anti-imperialism. That all of these elements are at the forefront of North Korean politics today may not be entirely attributable to the Manchurian guerrilla struggle, but its contribution can hardly be overestimated.

\section{MANCHURIA AS MYTH}

However, the real significance of the Manchurian experience for North Korea may lie not so much in its historical reality, but in its function as the central founding myth of the North Korean state. According to DPRK official history, everything the current North Korean state claims to representnationalism, socialism, the chuch'e ideology-is first imagined and articulated by Kim during his Manchurian exodus. The "mythification" of the Manchurian partisan struggle begins almost immediately after liberation, and has grown steadily over time. At the center of this, of course, is Kim Il Sung.

It is easy enough to expose the distortions, exaggerations, and outright lies in the North Korean story of Kim's "revolutionary struggle" in Manchuria. But to point out "factual errors" is to miss the point entirely. In the DPRK this experience is not history, but epic, a semireligious tale of loss and redemption. Although textual supports are used to demonstrate the "facticity" of these events-revolutionary graffiti carved into Manchurian trees, miraculously preserved from the 1930s; Japanese newspaper articles, genuine and forged--historical proof is ultimately irrelevant. North Korean historians can be compared to the chroniclers of the Middle Ages: "By basing their historical tales on a divine plan of salvation-an inscrutable one-they have from the very start lifted the burden of demonstrable explanation from their own shoulders." 37 
This "salvation" is of the nation (minjok), represented by Kim both politically and metaphorically. Kim is the premier nomad, whose wandering in the Manchurian wilderness stands for the exile of all Korean people from their colonized homeland. David Apter interprets Mao in Yanan as an Odysseus-figure, wandering in exile, who becomes a kind of "Chinese Socrates in full possession of logic and word. ${ }^{38}$ Kim also resembles Odysseus, but a more fitting image is Moses, leading the chosen people out from foreign oppression through a wilderness of exile to the promised land. How much Kim's Christian missionary education and deeply devout mother influenced this apparent use of Old Testament imagery may never be known. Needless to say, North Korean texts never acknowledge any such influence. ${ }^{39}$

At the age of twelve Kim "crossed the Yalu river into exile," ${ }^{, 40}$ determined to return to the center and recreate it. Whether or not the young Kim really had such thoughts, the experience of exile often creates a longing for the nation, perhaps even an imagining of the nation for the first time. The myth of Kim's Manchurian experience seems intended to stress the need for a powerful symbolic center in Korean politics, around which a nation can make sense of its existence; a center that is, in the words of Clifford Geertz, imbued with sacred authority and "connected to the way the world is built."4l

Kim himself is this lost center. In his recently published autobiography, Kim "remembers" that in 1931, after the failure of uncoordinated acts of sabotage and terrorism against Japanese authority, older and more experienced Korean resistance fighters took Kim as their leader because they realized that "in order to win back the country the twenty million Korean people must unite, and that in order to unite in mind and purpose they must have a center of leadership, a center of unity." ${ }^{42}$ In his interpretation of North Korea's "corporatist" ideology, Bruce Cumings uses the metaphor of concentric circles radiating outward from Kim Il Sung. Immediately surrounded by his family and his Manchurian cohorts, Kim is the center of power, benevolence and love expanding in ever-widening circles to embrace the whole Korean people. ${ }^{43}$ From the periphery of exile, Kim creates a new center and embodies it in his own person.

North Korean histories are strangely silent about Kim's activities between 1941 and 1945, perhaps because references to his retreat to the USSR would undermine Kim's image as an ever-victorious nationalist leader. Nevertheless, even during this period Kim is presented as the embodiment of revolutionary hopes whose reputation serves as "encouragement" for the workers, students, and peasants struggling against their colonial oppressors. Kim is the absent redeemer who will soon return to deliver his people to independence. According to Kim's official biography, in 1944 mysterious handbills appeared at the Pyongyang Arsenal saying "In a few days, General Kim Il Sung will come," while civilian guards in South Ch'ungch'ŏng put up a slogan reading 
"Youth of Korea . . . wait for Kim Il Sung to return in triumph." "44 By 1945 "the name of General Kim Il Sung became the sun and symbol of deliverance for the Korean people in all parts of the country from Mt. Baikdoo [Paektu] to Cheju Island in the South Sea.",45

This brings us back to Paektusan and Kim Jong Il's fishing excursion. To the ancient mythical, shamanistic significance of Paektusan has been added more contemporary connotations of the present North Korean state's revolutionary heritage. Although not the site of much actual guerrilla activity, Paektusan has become a prominent symbol of what Clifford Geertz called "the inherent sacredness of sovereign power." ${ }^{46}$ North Korean slogans seek to inspire the population with the "spirit of Mt. Paektu," well-publicized Youth League visits to the peak reenact (probably fictional) guerrilla battles, and citizens make "pilgrimages" to the Heavenly Lake. Over time, Paektusan has increased in prominence in North Korean propaganda, becoming perhaps the most important image, next to that of Kim himself - and the two are often portrayed together, Kim standing at the mountain's summit-through which the state symbolizes its legitimacy. In recent years, as we have seen, Paektusan has even been named as the fictive birthplace of Kim Jong Il, linking the younger Kim not only to his father's guerrilla struggles, but also to one of the most powerful images of Korea's culture and history. Paektusan, and Manchuria as a whole, function as a mythical space, the site of a revolution both inside and outside of Korea, both inside and outside of history; a frontier of unlimited possibility and, at the same time, a center, a home, the birthplace of the minjok.

\section{From Marxist Historiography to Chuch'e}

Paektusan does not appear much in North Korean mythography until the 1960s. (Kim Il Sung does not appear to have actually fought any battles in that area.) But it becomes increasingly identified with Kim Jong Il from the 1970s. To return to our original image, then, what was Kim Jong Il doing on Paektusan in the autumn of 1971? It was precisely at this time, in the early 1970s, when Kim Il Sung began to groom his son as his successor. Kim Jong Il gradually rose in prominence in the Worker's Party until his succession was made public at the Sixth Party Congress in October $1980 .^{47}$ By putting Kim Jong Il at the base of Paektusan in 1971, just as this process was about to begin, the North Korean state symbolically links him with the origins of the Korean race, to Tangun, to the center of Korean history and political power.

In addition, from the beginning of the 1960s onward Manchuria gradually becomes centered in a nationalist historiography that owes much more to Shin Ch'ae-ho than to Karl Marx. Rather than go over the development of North Korean historiography from the 1950 s to the late 1970 s, when a consensus was reached in the general periodization and articulation of North Korean 
historiography, let me encapsulate this development in two quotes. Marx began the Communist Manifesto with the famous declaration, "The history of all hitherto existing society is the history of class struggles. ${ }^{48}$ In contrast, a standard contemporary North Korean history begins with the statement, "Human history is a history of struggle of the people for Chajusŏng [autonomy or independence]." ${ }^{, 49}$ This is a subjective, nation-centered history that almost perfectly reflects Shin Ch'ae-ho's struggle between the "I" and the "non-I." Of course, the "I" in this case is Kim Il Sung, who represents the subjectivity of the Korean people.

North Korean historiography from the 1970s onward has stressed the unique, even sui generis, nature of Korean civilization going back to Old Chosŏn, whose capital, Wanggŏmsŏng, is now located in the Liao River basin in Manchuria rather than near Pyongyang. ${ }^{50}$ Nangnang, then, was not a Chinese commandery but a Korean kingdom, based in the area of Pyongyang. Slavery begins with the Three Kingdoms period, putting ancient Korea at a level of civilization equal to that of China. Finally, the North Korean histories argue against the concept of Unified Shilla and view Korea between the seventh and tenth centuries as divided between Shilla in the South and Parhae in the North, the latter seen as the successor to Koguryŏ. ${ }^{\text {s1 }}$ Korea, then, only becomes unified under Koryŏ.

However, it is in the modern period that the nationalist trope organizing North Korean historiography becomes most evident. Modern history (kŭndaesa) begins in the 1860 s and 1870 s, not so much because this is the period of incipient capitalism, as earlier North Korean histories argued, but because this is the moment of foreign encroachment and nationalist resistance. Indeed, the beginning of kündaesa can be precisely dated to 1866 , when the USS General Sherman sailed up the Taedong river and was attacked by a patriotic mob led by Kim Il Sung's great-grandfather, Kim Ǔng-u. Similarly, contemporary history (hyŏndaesa) no longer begins in 1945, with liberation and the beginnings of socialism, but in 1926, when Kim Il Sung allegedly formed the "Down With Imperialism Union" in Jilin City, Manchuria, to fight against the Japanese. ${ }^{52}$

Kim Il Sung's death in July 1994 and Kim Jong Il's succession to power signify the passing of North Korea's first generation of guerrilla revolutionaries. The few hundred Manchurian cohorts of Kim Il Sung, who have formed the core of the DPRK leadership since the regime's inception in 1948, will soon all be gone from the scene. Nevertheless, the system they established remains in place, a system created in part out of their exile experience, a society held together by "iron discipline" against a hostile outside world, which one Japanese scholar describes as a "guerrilla band state" (yügekitai $k o k k a) .{ }^{53}$ The DPRK has attempted to maintain an unbreakable bond between the new leadership and the old, and to place Kim Jong Il's own past into the 
Manchurian exile movement, even putting his birthplace, like that of Tangun, atop Paektusan. It is still too early to know whether the dream of exile that was the formative experience of North Korea's first leaders and the founding myth of the state they created can sustain North Korea in the future, or whether new narratives of the nation will have to be written.

\section{NOTES}

1. Korea Today, February 1994.

2. The mountain also made a profound impact on some of the early Western explorers who visited the area in the age of high imperialism. See H. E. M. James, The Long White Mountain, or A Journey in Manchuria (New York: Greenwood Press, 1968 [1888]).

3. Cited in Benedict Anderson, "Exodus," Critical Inquiry 20, no. 2 (Winter 1994), p. 314.

4. Homi K. Bhabha, Nation and Narration (London: Routledge, 1990), p. 291.

5. Key S. Ryang, "Sin Ch'ae-ho and Modern Korean Historiography," The Journal of Modern Korean Studies 4 (May 1990), p. 29.

6. Michael Robinson, "National Identity and the Thought of Sin Ch'ae-ho: Sadaejuüi and Chuch'e in History and Politics," Journal of Korean Studies 5 (1984), p. 123.

7. Ryang, "Sin Ch'ae-ho," p. 30.

8. Shin Ch'ae-ho, Chosŏn sangosa [Chosŏn antiquity], in Tanjae Shin Ch'ae-ho chŏnjip (Seoul: Tanjae Shin Ch'ae-ho sǒnsaeng kinyŏm saŏphoe, 1987), vol. 1, pp. 31-32.

9. Ryang, "Sin Ch'ae-ho," p. 40.

10. S. N. Eisenstadt points out that it is precisely these kinds of "free floating elements" that in times of social crisis are able to challenge existing authority structures and articulate new cosmologies and visions of political order. See Revolution and the Transformation of Societies: A Comparative Study of Civilizations (New York: Free Press, 1978).

11. This term, which brings together the activities of capitalism, imperialism, and war in their linked historical development, is from Gilles Deleuze and Felix Guattari, A Thousand Plateaus: Capitalism and Schizophrenia, tr. by Brian Massumi (Minneapolis: University of Minnesota Press, 1987 [1980]), pp. 351-432.

12. Ki-baik Lee, A New History of Korea, tr. by Edward W. Wagner with Edward J. Shultz (Seoul: Ilchogak, 1984), p. 253.

13. For a study of the hwajonmin and their increase in the colonial period, see Kang Man-gil, "The life of the hwajŏnmin," in Iljeshidae pinmin saenghwalsa yŏngu [The life of the poor in the Japanese colonial period] (Seoul: Ch'angjak kwa pip' yŏngsa, 1987), pp. 117-234.

14. Lee, A New History of Korea. In 1986 when my wife and I went to Changchun in Northeast China to teach for a year, my mother-in-law said that she "could not help feeling sad" because she remembered from her Korean childhood that "only desperately poor people went to Manchuria."

15. See Robert H. G. Lee, The Manchurian Frontier in Ch'ing History (Cambridge: Harvard University Press, 1970).

16. Gavan McCormack, Chang Tso-lin in Northeast China, 1911-1928: China, Japan and the Idea of Manchuria (Stanford: Stanford University Press, 1977), p. 3.

17. Thomas Gottschang, "Economic Change, Disasters and Migration: The His- 
torical Case of Manchuria," Ph.D. dissertation, University of Michigan, 1985. Cited in Edward Friedman, Paul G. Pickowicz, and Mark Selden, with Kay Ann Johnson, Chinese Village, Socialist State (New Haven: Yale University Press, 1991), p. 20. See also Wang Guishan et al., Jindai dongbeishi [Modern history of the Northeast] (Harbin: Heilongjiang chubanshe, 1984).

18. Henry G. Schwartz, The Minorities of Northern China: A Survey (Bellingham: Western Washington University, 1984), p. 207; Pak Ch'ang-uk, "Korean Migration in China," Yŏksa pip'yŏng 15 (Winter 1991), p. 182.

19. Sun Chunri, "The Formation of Korean Areas Around Yanbian in Jilin Province," Minzu yanjiu (January 1990), p. 87.

20. For a brief history of the Korean community in China, see Chae-jin Lee, China's Korean Minority: The Politics of Ethnic Education (Boulder: Westview Press, 1986).

21. Chosŏnjok yaksa [Brief history of the Korean nationality] (Yanji: Chosŏnjok yaksa p'yŏnch'anjo, 1986), p. 74; F.C.Jones, Manchuria Since 1931 (New York: Oxford University Press, 1949), p. 69. Due to the difficulty of obtaining accurate population records in remote Manchuria at this time, there is no precise agreement on the size of the Korean community, but the influx of Koreans in the first half of the twentieth century was certainly huge. For a contemporary investigation of Koreans in Manchuria, see Yi Hun-gu, Manju wa Chosŏnin [Manchuria and the Koreans] (Pyongyang, 1931).

22. Pak Ch'ang-uk, "Korean Migration in China," pp. 186, 189. Indebtedness to Chinese landlords was one reason for the peripatetic lifestyle of the Korean immigrants. In Yi Hun-gu's 1931 survey, 80 percent of the families interviewed had moved three to seven times since arriving in Manchuria. Cited in Schwartz, The Minorities of Northern China, p. 209.

23. See Yi Hun-gu's survey of Jiandao residents, reproduced in Kim Ch' ang-sun and Kim Chun-hwa, Hanguk kongsanjuŭi undongsa [The Korean communist movement], vol. 4 (Seoul: Korea University Press, 1974), p. 17. When asked, "Why did you come to Manchuria?" 135 out of 201 respondents $(67 \%)$ answered either "To improve the conditions of my life," "Because of poverty at home," or "Because of economic distress in Korea."

24. Kim and Kim, Hanguk kongsanjuŭi undongsa. Later, communist groups also seem to have had a hand in the opium trade. Zhang Zhenglu's recent study of the civil war in Manchuria, Bai xue, hong xue [White snow, red blood] (Beijing: Renminjun chubanshe, 1989), suggests that CCP troops smuggled large quantities of the drug. Opium smuggling from Manchuria into Korea remained a problem after 1945. See U.S. Army Far East Command, Records Seized by U.S. Military Forces in Korea, RG 242, shipping advice 2007, boxes 1-6, materials on Injegun, Kangwŏn Province.

25. McCormack, Chang Tso-lin in Northeast China, p. 16.

26. Lee, A New History of Korea, pp. 95, 105. See H. E. M. James, The Long White Mountain, especially pp. 247-270 on the Changbaishan region.

27. McCormack, Chang Tso-lin in Northeast China, p. 20.

28. See Eisenstadt, Revolution and the Transformation.

29. Robert A. Scalapino and Chong-sik Lee, Communism in Korea (Berkeley: University of California Press, 1972), p. 5. Even before annexation, ŭibyŏng groups had set up exile bases from which to attack the Japanese. In April 1908, for example, a group of about 1000 ŭibyŏng based in the Russian Maritimes attacked a Japanese army unit in North Hamgyŏng Province. See Mikhail Park, "The Anti-Japanese Korean 
Independence Movement in Russian Territories: The 1920s and 1930s," Korea Journal 30, no. 6 (June 1990), p. 38.

30. That is not to say that all Korean armed insurgents in Manchuria were communists. Before the Japanese entered Manchuria, noncommunist nationalists were also involved in military training for Korean anti-Japanese activists. Kim San describes his entrance into the Manchuria-based military school of the Korean Army of Independence in the 1920s in his Song of Ariran: The Life Story of a Korean Rebel (New York: John Day, 1941), pp. 104-107.

31. Se Hee Yoo, "The Communist Movement and the Peasants: The Case of Korea," in Peasant Rebellion and Communist Revolution in Asia, ed. by John W. Lewis (Stanford: Stanford University Press, 1974), pp. 69-74.

32. Scalapino and Lee, Communism in Korea, p. 200. According to Japanese sources, 86 percent of arrests in connection with the Red Peasant Movement in 1931 and 1932 were in the Hamgyong provinces.

33. Dongbei kangrijun shiliao [Historical materials of the Northeast Anti-Japanese United Army] (Beijing: Zhonggondang shiliao chubanshe, 1987), vol. 1, p. 6. North Korean materials from the late 1940s do refer to Kim's involvement with the CCP, but such references disappear in the 1960s.

34. "The Northeast Anti-Japanese United Army was the anti-Japanese armed struggle of the various nationalities of the Northeast, created and led by the Chinese Communist Party." Dongbei kangrijun shiliao, p. 1. For a criticism of this CCPcentered approach by an ethnic Korean in China, see Pak Ch'ŏng-san, "Serious Distortions in Studies of Korean Nationality Activities in China," Yŏksa pip'yŏng 15 (Winter 1991), pp. 223-234.

35. Some Chinese sources do, however, lend equal weight to Chinese and Korean activists in Manchuria as engaging in a joint struggle for the independence of China and Korea, respectively. See Jiang Niandong et al., Wei Manzhouguoshi [History of Manchukuo] (Changchun: Jilin renmin chubanshe, 1980), p. 551. The notorious Minsaengdan incident of 1935, in which Korean spies for the Japanese police infiltrated Chinese Communist circles and led to a bloody purge of Korean communists, epitomized the tension and mutual suspicion existing between Koreans and Chinese. See Dae-Sook Suh, Kim Il Sung, The North Korean Leader (New York: Columbia University Press, 1988), pp. 32-34.

36. Kim's report, "Kanglian diyi lujun lueshi" [Brief history of the First AntiJapanese United Army] appears in Dongbei kangri lianjun shiliao [Historical materials of the Northeast United Anti-Japanese Army] (Beijing: Zhonggongdang sheziliao chubanshe, 1987), vol. 2, pp. 665-679. Kim Ch'aek and Ch'oe Yong-gŏn, two of the most prominent Manchurian veterans in the DPRK, also submitted reports that appear in this volume.

37. Walter Benjamin, "The Storyteller," from Illuminations (New York: Schocken Books, 1968), p. 96.

38. David Apter, "Yan' an and the Narrative Reconstruction of Reality," Daedalus 122, no. 2 (Spring 1993), p. 211.

39. For Kim's religious background, see Yŏng-ho Ch'oe, "Christian Background in the Early Life of Kim Il-song," Asian Survey 26 (October 1986), pp. 10821091. North Korean histories present Kim's parents not as Christians, but as revolutionary patriots. Thus, in a remarkably Confucian twist, Kim is given further legitimacy by his revolutionary ancestry. Unlike Mao, who confronts his reactionary father and leaves home, Kim is not a rebel but a true hyoja or filial son. Loyalty to one's 
parents, to the revolution, and to the North Korean state are thus identified and mutually reinforcing.

40. A recurrent image among Korean nationalists in Manchuria. See Kim San, Song of Ariran, p. 59.

41. Clifford Geertz, Local Knowledge: Further Essays on Interpretive Anthropology (New York: Basic Books, 1983), p. 124.

42. Kim Il Sung, Reminiscences: With the Century, vol. 2 (Pyongyang: Foreign Languages Publishing House, 1992), p. 108.

43. Bruce Cumings, "Corporatism in North Korea," Journal of Korean Studies 4 (1982-83), p. 291. p. 521.

44. Baik Bong, Kim Il Sung: Biography, vol. 1 (Beirut: Dar Al-Talia, 1973),

45. Baik Bong, Kim Il Sung, p. 523.

46. Geertz, Local Knowledge, p. 123.

47. Suh, Kim Il Sung, pp. 276-281.

48. Robert C. Tucker, ed. The Marx-Engels Reader, 2d ed. (New York: W. W. Norton, 1978), p. 473.

49. Kim Han Gil, Modern History of Korea (Pyongyang: Foreign Languages Publishing House, 1971), p. 3.

50. Yŏng-ho Ch'oe, "Reinterpreting Traditional History in North Korea," Journal of Asian Studies 49, p. 506.

51. Ch'oe, "Reinterpreting Traditional History," pp. 506-510.

52. For the definitive North Korean interpretation of Korean history, from the Stone Age to the present, see the 33-volume Chosŏn chŏnsa [Complete history of Korea] (Pyongyang: Kwahak-paekkwasajon ch'ulp'ansa, 1983). Kim Il Sung's family past and youthful exploits are recorded in Baik Bong, Kim Il Sung.

53. Wada Haruki, Kin Nichisei to Manshu kōnichi sensō [Kim Il Sung and the Anti-Japanese War in Manchuria] (Tokyo: Heibonsha, 1992), p. 377. 